\title{
РЕАЛІЇ І ПЕРСПЕКТИВИ БОЛОНСЬКОГО РЕФОРМУВАННЯ У ВНЗ УКРАЇНИ
}

\author{
Ю. М. Колесник, Ю. М. Нерянов, М. О. Авраменко, К. І. Гейченко \\ Запорізький державний медичний університет
}

\section{REALITIES AND PERSPECTIVES OF BOLOGNA REFORMING IN UKRAINIAN HIGHER EDUCATIONAL INSTITUTIONS}

\author{
Yu. M. Kolesnyk, Yu. M. Nerianov, M. O. Avramenko, K. I. Heichenko \\ Zaporizhzhya State Medical University
}

\begin{abstract}
У статті розглядається головна лінія розвитку вищої освіти України у контексті принципів Болонської системи, яка передбачає реалізацію концепції створення єдиного європейського освітнього простору. Описано реалії і перспективи впровадження болонського реформування на прикладі роботи Запорізького державного медичного університету, серед яких є якість вищої освіти, академічна інтеграція студентів і викладачів, наукова співпраця, інформатизація освітнього процесу. Відзначено позитивні моменти та проблеми стану сучасної освіти України з метою її вдосконалення і подальшої євроінтеграції.
\end{abstract}

The article deals with the main direction of Ukrainian higher education development in the context of Bologna system, which presupposes creation of the common European higher education area. Realities and perspectives of the implementation of Bologna reforming are elucidated using the example of Zaporizhzhya State Medical University. These include quality of education, academic integration of students and teachers, scientific cooperation, informatization of educational process. Positive and negative aspects of modern Ukrainian education are pointed out with the aim of further perfection and European Integration.

Вступ. Сучасний етап розвитку світової спільноти характеризується зростаючою роллю освіти, яка активно впливає на ії стан і визначає основи економічного і соціального прогресу як усієї людської цивілізації, так і окремих держав і народів. Благополуччя i безпека суспільства, успіхи і результати його розвитку практично в усіх сферах і напрямах діяльності суттєво залежать від рівня освіченості його членів, що забезпечується досягненнями в галузі освіти.

Останніми роками в освіті склалася тенденція до інтернаціоналізації і інтеграції, створено передумови для побудови загального європейського освітнього простору зі збереженням особливостей і досягнень національних освітніх систем.

Сьогодні перед Україною стоїть завдання формування системи освіти, яка б відтворювала культурний та інтелектуальний потенціал, здатний вивести суспільство $з$ кризи і надати йому необхідний запас міцності для входження до загальносвітового простору, у тому числі й освітнього. У сучасному світі знання стали значимим чинником виробництва, що забезпечує найбільшу віддачу від інвестицій. Болонський процес $\epsilon$ частиною економіки знань, яка зароджується.

() Ю. М. Колесник, Ю. М. Нерянов, М. О. Авраменко,

К. І. Гейченко
Освіта за радянських часів вважалася фундаментальною та однією з кращих у світі, проте вже давно змінилися вимоги, яким має задовольняти освіта сьогодні, що, звичайно, потребувало реформування. Вважається, що навіть у стаціонарному стані суспільства оновлення вищої освіти повинне відбуватися через 25-30 років. Міжнародна практика такого реформування передбачає, що оновлення має бути сконцентрованим на змісті освіти, його структурі, технології навчання і ресурсному забезпеченні. Саме це дозволить зробити реформи вітчизняної освіти послідовними, змістовними і гнучкими.

Основна частина. Майже 10 років впровадження Болонської кредитно-модульної і модульно-рейтингової технології навчання у національну систему вищої освіти України дозволяють узагальнити накопичений досвід і зробити певні висновки про ефективність даного нововведення.

В цілому як позитивний ефект необхідно зазначити, що приєднання України до Болонського процесу дало новий імпульс модернізації вищої професійної освіти, тобто отримано певний зовнішній стимул для внутрішніх реформ. Впровадження Болонської системи відкрило додаткові можливості українським ВНЗ для участі у проектах, що фінансуються Свро- 
пейською комісією, а студентам і викладачам вищих навчальних закладів - в академічних обмінах з університетами європейських країн.

У Запорізькому державному медичному університеті в контексті болонського реформування розроблено концепцію, в основу якої покладено підготовку освіченого, інтелектуального, творчого фахівця, що вміє адаптуватися до соціально-економічного середовища, що швидко змінюється, раціонально організовувати самостійну пізнавальну діяльність, має власну думку.

Питання модернізації процесу навчання у ЗДМУ та підвищення його якості постійно знаходиться у полі зору ректорату, деканатів та кафедр.

В університеті є вузівський координатор з проблем реалізації освітніх технологій за кредитно-модульною системою. Було розроблено рекомендації для кафедр з впровадження нової системи в університеті. Система кредитів отримала широке розповсюдження на всіх кафедрах ЗДМУ і знайшла втілення у нових інтегрованих програмах і робочих планах, створених на кожній кафедрі.

Отримані на сьогодні результати впровадження модульного навчання свідчать про подолання першого етапу становлення та адаптації навчально-виховного процесу до нової системи. Так, порівняно 3 2010 роком (останній випуск студентів, що навчались за традиційною системою) у 2013 році показники якісної успішності на державних іспитах випускників зі спеціальності "Лікувальна справа" підвищились: на 3,25 \% збільшилась кількість студентів, які отримали диплом з відзнакою; на 3,87 \% зменшилась кількість випускників, що склали іспити тільки на “'3”; на 8,88 \% підвищився показник якісної успішності та поліпшився середній бал вітчизняних студентів, де якісна успішність склала 70 \%. Стабільність якості підготовки випускників з усіх спеціальностей підтверджують і результати комплексних державних іспитів “Крок”. У 2013 році за результатами “Крок-2. ЗЛП” університет посів друге місце з результатом 80,5 \%, що перевищує національний показник на 4,1%. За результатами МЛI “Крок-2. Фармація” університет також був на другому місці серед медичних ВН3 України з результатом 90,3 \%, перевершивши майже на 6 \% національний показник. Як і минулого року, бюджетні інтерни одержали перше місце, набравши 81,1 \% правильних відповідей.

При цьому слід зазначити, що нам вдалося зберегти позитивні напрацювання і традиційної вітчизняної системи та поєднати ії з новаціями сучасності.

Важливим аспектом, який позитивно впливає на усю систему навчання, $є$, безумовно, контроль якості ос- віти. В університеті розроблені єдині критерії і єдиний підхід до оцінки знань студентів, що включає: на piвні ВНЗ - політику ВНЗ щодо оцінки студентів; на рівні факультету - стандарти контролю якості навчання студентів для проміжної модульної атестації і підсумкової державної атестації випускників за фахом (напрямом); на рівні кафедри - стандарти контролю якості навчання для поточної і проміжної атестації студентів, а також для оцінки контролю модулів. На порядку денному стоїть питання впровадження системи автоматизованого контролю успішності і відвідування студентів.

Таким чином, в університеті реалізується модульно-рейтингова технологія навчання, яка дає можливість активно впливати на процес оволодіння знаннями, уміннями і навичками, покращувати його функціональні характеристики, що дозволяє підняти інтерес студентів до навчального процесу і, відтак, підвищити їхню успішність.

Модульна система має за мету поставити студента перед необхідністю регулярної навчальної роботи впродовж усього періоду навчання. На нашу думку, модульно-рейтингова система оцінки знань студента є якісно новим рівнем навчання у вищій школі. В основі їі лежить безперервна індивідуальна робота 3 кожним студентом.

Для впровадження рейтингової системи потрібна наявність стабільних програм (для порівняння: за останні 9 років навчальні плани за фахом "Лікувальна справа" змінювались 5 разів) і повного дидактичного оснащення_освітніх стандартів. Усе це вимагає чималих фінансових витрат на розробку відповідного програмного забезпечення і його впровадження у навчальний процес, що є зараз досить проблематичним.

Забезпечення якості освіти і посилення контролю за ним здійснюється головним чином через тестування. При певних позитивних моментах використання тестового контролю в той же час приводить до дегуманізації освітнього процесу через безпідставне звуження безпосередньої комунікації між студентом та викладачем. Деградація усного слова, вербальності як основної ознаки “людини розумної”, занедбання формальної логіки усного мовлення призводить до занедбання правил наукового мислення, аргументації, зниження ефективності пізнавальних зусиль, до блокування евристичного потенціалу студента, недопущення права на власну думку. Пошук відповіді з декількох готових варіантів не $є$ творчим, як це відбувається під час усного іспиту/заліку. Тестові завдання - це, як правило, тільки епізод інформаційного потоку, вони не можуть показати глибину і міру засвоєння знань студентом. 
Отже, зайва формалізація форм контролю з використанням тестування нівелює особистість студента, його творчу природу мислення. Усе це діє не на користь науці та освіті. Тому нам здається, що застосування тестового контролю повинне доповнювати обов'язкове вербальне спілкування викладача і студента на різних етапах контролю.

Однією з переваг Болонської системи є розвиток академічної мобільності студентів і викладачів. Для студентів вона відкриває нові можливості для навчання і професійної підготовки. Так, в 2012-2013 навчальному році студенти нашого університету проходили навчання за обміном в медичних університетах Польщі, Чехії, Казахстану. Цього року планується розширення освітніх контактів з ВНЗ Болгарії, Білорусі, Прибалтики, Росії, Казахстану, Чехії і Польщі. Запорізьким державним медичним університетом укладено 23 договори про співпрацю з іншими університетами, географія яких представлена як країнами близького (Узбекистан, Грузія, Латвія, Литва тощо), так і далекого зарубіжжя (Велика Британія, Греція, Канада, Нігерія, Кіпр). На етапі підписання знаходиться низка договорів з іншими медичними ВНЗ Свропи, Азії та Америки. Цінність таких контактів і обмінів важко переоцінити. Зрозуміло, що висока міра академічної мобільності студентів передбачає розвинену інфраструктуру і доступність джерел фінансування, що, на жаль, далеко не завжди реально. Система освіти не може існувати і розвиватися виключно за рахунок ринкових форм. Усі поїздки за кордон наших студентів здійснюються на кошти батьків, спонсорів і різних фондів. А в економічно розвинених країнах державне фінансування виступає гарантом реалізації принципу справедливості у забезпеченні доступу до вищої освіти і його ефективності. Саме фінансова неспроможність держави і ВНЗ країни не дозволяє доки розглядати академічну мобільність студентів як пріоритетний напрям у професійній підготовці майбутніх фахівців. Хоча для нас важливо, щоб наші студенти привозили досвід навчання в інших зарубіжних методичних системах, що може стати стимулом для позитивних перетворень в організації освітнього процесу у вітчизняних вищих навчальних закладах.

Завдяки мобільності іноземних студентів, що приіжджають за обміном, ми отримуємо додаткове джерело позабюджетного фінансування. Зрозуміло, що економіка такої мобільності студентів має ще бути вивченою, проте вже зараз вимальовуються перспективи деякого поліпшення матеріального становища приймаючого ВНЗ.
Важливо підкреслити, що використання російської мови як засобу здобуття освіти дозволить нам приймати на навчання студентів з держав СНД і прилеглих держав, які будуть особливо зацікавлені в якісній українській освіті.

Проте, як нам здається, до питання мобільності студентів треба підходити з певною часткою обережності, оскільки соціально-культурний і економічний вплив тих держав, де наші студенти проходили навчання за обміном, може викликати у них стійке бажання поміняти і місце постійного проживання.

Щодо мобільності професорсько-викладацького складу, ми усвідомлюємо той факт, що університет таким чином дістає нову можливість здійснювати реальне підвищення професійної майстерності своїх співробітників, що сприятиме і підйому наукової активності на кафедрах.

У зв'язку з цим виникає важлива проблема глибокого вивчення іноземних мов. Свропейці у своїй більшості вільно говорять двома-трьома мовами. У нас така тенденція не спостерігається, і звичайна школа ще не здатна розв' язати це завдання сьогодні.

У ЗДМУ до усіх викладачів також пред'являється вимога володіння англійською на рівні читання лекцій з відповідної дисципліни. Для тих же, хто не володіє, в університеті організовані різнорівневі курси при кафедрі іноземних мов. Усі викладачі та усі кафедри обов' язково беруть участь у рейтингу, що стимулює їхн роботу і передбачає ефект змагання.

32012 року Запорізький державний медичний університет активно співпрацює з Canadian College of English language. У межах цього проекту студенти, магістри, аспіранти і співробітники університету активно вивчають англійську мову за програмою SMRT. У 2014 році вже 30 осіб зі 100 учасників програми отримали сертифікати, що підтверджують відповідний рівень володіння англійською мовою.

Сучасні інноваційні технології, які розроблено Canadian College of English language, дозволяють вивчати англійську мову, використовуючи усі сучасні Інтернет-ресурси, незалежно від місця знаходження, розкладу і міри зайнятості.

Досвід роботи з цією програмою підтвердив ефективність даного підходу, оскільки завдяки зацікавленості і вмотивованості слухачі показали високі результати, що доводить перспективність подальшої співпраці з Canadian College of English language.

У період зарубіжних стажувань, які мають бути плановими за програмами мобільності викладачів, останні, крім оновлення спеціальних знань, освоєння позитивного зарубіжного досвіду, зможуть займати- 
ся вдосконаленням своєї професійної англійської або якоїсь іншої іноземної мови. Крім того, з'являється реальна можливість запрошувати кваліфікованих іноземних фахівців, що сприятиме зростанню рівня навчання у вітчизняних ВНЗ, створюючи більш конкурентне професійне середовище. А це, у свою чергу, $є$ позитивним стимулом і для організації ефективного навчання вітчизняних студентів англійської як мови європейського освітнього простору.

Останніми роками бібліотечний фонд нашого університету поповнюється англомовною літературою, яка сприяє розширенню професійного кругозору викладачів і активізації їхньої наукової діяльності, а також використовується іноземними студентами для самостійного опанування матеріалом, що вивчається. Розширення наукових контактів і спільні наукові дослідження з європейськими університетами, безумовно, позитивно позначаться на розвитку науково-дослідної роботи українських ВНЗ. У 2012 році наш університет спільно з університетами Великої Британії, Греції і Кіпру став учасником проекту TEMPUS/TACIS, в основу якого покладено програму проблемно-зорієнтованого професійного навчання. Проект фінансується Свропейською радою. Його завданнями є створення нової навчальної програми, проблемно-зорієнтованого навчання з використанням віртуальних пацієнтів, а також підтримка і розвиток системи електронного навчання, підготовка професорсько-викладацького складу до впровадження нової навчальної програми таїі поширення на національному рівні.

Зараз група викладачів від усіх кафедр університету займається адаптацією кейсів, розроблених Лондонським університетом, до умов української системи охорони здоров'я.

Така співпраця позитивно впливає не лише на якість навчання студентів, але й дає можливість розробляти нові принципи керування навчальним процесом, створювати сучасну науково-методичну базу, прогресувати науку.

Сьогодні актуальним є питання підготовки наукових кадрів. I не зважаючи на те, що в ЗДМУ науковому зростанню викладачів приділяється велика увага (105 докторів наук і 414 кандидатів наук), ректорат постійно працює з науковим резервом. Для цього на передвипускних курсах створено 3 групи студентів з числа творчої молоді, які протягом усього періоду навчання успішно займалися в кафедральних наукових гуртках і товариствах та виявили науково-дослідні здібності.

Ще одним важливим напрямом оновлення освітнього процесу (або принципом болонського рефор- мування) ВНЗ є його інформатизація. Стратегічна мета інформатизації освіти полягає в глобальній раціоналізації інтелектуальної діяльності за рахунок використання нових інформаційних технологій, радикальному підвищенні ефективності та якості підготовки фахівців з новим типом мислення, відповідним вимогам сучасного суспільства. Ректорат вважає своїм завданням формування єдиного інформаційно-методичного простору, активного використання у навчальному процесі інформаційних і комунікаційних технологій, по-перше, для підвищення якості професійної підготовки студентів і для практичного використання викладачами інформаційних технологій з метою наукового і кар'єрного росту, по-друге, для співпраці iз зарубіжними ВНЗ-партнерами. У цьому напрямку зроблено чимало: створено наукову бібліотеку з електронним фондом навчально-методичної і наукової літератури; у навчальному процесі використовується методика дистанційних освітніх технологій (читання лекцій, телеконференціiі); працюють 42 комп’ютерні класи; здійснено підключення до локальної і глобальної мережі Інтернет аудиторій кафедр, служб, студентських гуртожитків; обладнано цифровими комплектами лабораторії; розробляються навчальні та контролюючі мультимедійні програми.

У 2013 році співробітниками ЗДМУ використано результати 50 передових наукових технологій, які включено до Реєстрів галузевих нововведень. Значну увагу університет приділяє розвитку програмних сервісів для навчального процесу. Так, впроваджено в експлуатацію та розміщено в мережі Інтернет сервер електронних ресурсів кафедр. Навчально-методична інформація 3 даного сервера через мережу Інтернет $є$ доступною студентам і викладачам кафедр для актуалізації інформації незалежно від часу та місця знаходження.

Впроваджено новий поштовий сервер з розширеними функціями, який дозволяє користувачам мати доступ до нього не тільки через локальну мережу, а також і через глобальну мережу Інтернет. Це дозволить організувати обмін інформацією та документами для навчального процесу. Створення єдиного інформаційного простору університету формує структуру з активного використання технологій дистанційного навчання. Сьогодні освітній простір університету вийшов далеко за межі кампусу і клінічних баз. Сформована корпоративна освітня мережа ЗДМУ включає два рівні: рівень обласної мережі і регіональний. Проте тут $є$ певні проблеми, а саме: неякісні лінії зв’ язку і відсутність у деяких викладачів необхідного досвіду такого навчання. 
При зазначених досягненнях впровадження болонської системи у ВНЗ України на сьогодні залишаються ще нерозв'язаними такі питання:

- не визначено повномасштабну національну ідею інтеграції України до єдиного європейського освітнього простору;

- не розроблено в повному обсязі національну стратегію з урахуванням національних інтересів у зв'язку з приєднанням до Болонського процесу;

- ВНЗ України повинні мати більше свободи у формуванні своєї стратегії, визначати власні пріоритети в навчанні і проведенні наукових досліджень, витрачати ресурси, профілювати свої програми з визначенням їхньої структури і змісту, встановлювати власні критерії для прийому студентів і викладачів;

- система накопичення залікових кредитів, дійсно, $\epsilon$ здатною зробити прозорими навчальні досягнення студентів, але при цьому не можна відкидати вже напрацьовані національні методики і технології.

На нашу думку, рано відмовлятися від семестрових іспитів, оскільки вони дають великий педагогічний і професійний ефект;

- у забезпеченні успішності реформування сучасної української освіти широко представлені розрізнені ідеї впровадження нових форм навчання і контролю його якості, але відсутня ідея принципової модернізації змісту освітніх програм;

\section{Література}

1. Андрущенко В. П. Модернізація педагогічної освіти України в контексті Болонського процесу / В. П. Андрущенко // Вища освіта України. - 2004. - № 1. - С. 5-10.

2. Болонські декларації в системі вищої освіти і науки України // Освіта. - 2004. - № 8. - 11-18 лютого.

3. Болонський процес: Нормативно-правові документи / Укл.: З. І. Тимошенко, І. Г. Оніщенко, А. М. Грєхов, Ю. Палеха. -К. : Вид-во Європ. ун-ту, 2004. - 102 с.

4. Бурик М. Болонский процесс в мире и на Украине / М. Бурик // Пропаганда. -2009. - [Электр. pecypc]. - http:/ /propaganda-journal.net/1151.html

5. Кремень В. Болонский процесс: сближение, а не унификация / В. Кремень // Зеркало недели. - 2003. - № 48 (473). - [Электр. pecypc]. - http//www.mirror.kiev.ua

6. Корсак К. Мифы о Болонском процессе / К. Корсак //
- сьогодні не створені необхідні умови для розвитку академічної мобільності студентів і викладачів;

- скорочення годин з гуманітарних дисциплін також не є бажаним, оскільки в цьому випадку виховати усебічно і гармонійно розвинену, моральну особистість, що є дуже актуальним нині, буде проблематично;

- забезпечення високої якості підготовки національних кадрів для зарубіжних країн у вищих навчальних закладах України повинне стати важливою складовою частиною глобального розвитку української освіти;

- інформаційна відкритість ВНЗ має бути максимальною;

- потрібна регулярність повної інформованості посадовців ВНЗ про сучасний стан справ в українській і європейській освіті.

Усі ці проблеми є переборними, проте сьогодні вони $\epsilon$ стримуючим чинником в тому, щоб освітню систему України зробити більш якісною і конкурентоспроможною, а випускників вітчизняних ВНЗ більш затребуваними на світовому освітньому ринку.

Висновок. Таким чином, болонське реформування в Україні свідчить, з одного боку, про позитивні зміни, які стимулюють інноваційну діяльність ВНЗ, а з іншого - про необхідність розв'язання існуючих проблем та подальшої модернізації вітчизняної вищої освіти.

Зеркало недели. -2005. - № 39 (567). - [Электр. ресурс]. http://www.zn.ua/3000/3300/51424/

7. Пидаев А. В. Болонский процесс в Европе. Что это такое и нужен ли он Украине? Возможна ли интеграция медицинского образования Украины в Европейское образовательное пространство? / А. В. Пидаев, В. Г. Передерий. -Одесса : Одес. гос. мед. ун-т, 2004. - 192 с.

8. Фирсов А. Д. Болонский процесс в Украине: точка зрения / А. Д. Фирсов // Траектория. - 2007. - [Электр. pecypc]. - http://www.trajectory.org.ua/analytics/educationviewpoint/bolon_proc.html

9. Штефан Л. В. Гуманізація самостійної роботи шляхом втілення сучасних педагогічних технологій / Л. В. Штефан // Болонський процес: модернізація системи вищої освіти УКраїни : матеріали VI Міжнар. наук. конф.-К., 2007.-C. 76-81. 